\title{
Bioactivity Studies of Datura metel, Aegle marmelos, Annona reticulata and Saraca indica and their Green Synthesized Silver Nanoparticle
}

\author{
Antony V. Samrot ${ }^{1 *}$, Silky ${ }^{2}$, Vijay Ignatious $C^{2}{ }^{2}$, Raji P. ${ }^{2}$, SaiPriya C. ${ }^{2}$ and Jenifer \\ Selvarani A. ${ }^{2}$
}

${ }^{1}$ Department of Biomedical Sciences, Faculty of Medicine and Biomedical Sciences, MAHSA University, Jalan SP2, Bandar Saujana Putra, 42810, Jenjarom, Selangor, Malaysia. ${ }^{2}$ Department of Biotechnology, School of Bio and Chemical Engineering, Sathyabama Institute of Science and Technology, Sholinganallur, Rajiv Gandhi Salai, Chennai, Tamil Nadu - 600 119, India.

\begin{abstract}
In this study, various plants like Datura metel, Aegle marmelos, Annona reticulata and Saraca indica were collected and subjected for extraction using various solvents, namely Water, Chloroform and Ethanol. The extracts were done with TLC bioautography for Antioxidant activity and Antibacterial activity, Minimum Inhibitory Concentration, Antibacterial activity, Antioxidant activity (DPPH and FRAP) and Phytochemical analysis. Plants used in this study showed antibacterial and antioxidant activity. These extracts were further utilized for Silver nanoparticle production and were characterized. Silver nanoparticles were utilized for In vitro antibacterial activity, where they did not show any antibacterial activity.
\end{abstract}

Keywords: Antioxidant activity; antibacterial activity; silver nanoparticles.

\footnotetext{
*Correspondence: antonysamrot@gmail.com

(Received: 05 February 2019; accepted: 06 March 2019)
}

Citation: Antony V. Samrot, Silky, Vijay Ignatious C., Raji P., SaiPriya C. and Jenifer Selvarani A., Bioactivity Studies of Datura metel, Aegle marmelos, Annona reticulata and Saraca indica and their Green Synthesized Silver Nanoparticle, J Pure Appl Microbiol., 2019; 13(1):329-338 doi: 10.22207/JPAM.13.1.36

(c) The Author(s) 2019. Open Access. This article is distributed under the terms of the Creative Commons Attribution 4.0 International License which permits unrestricted use, sharing, distribution, and reproduction in any medium, provided you give appropriate credit to the original author(s) and the source, provide a link to the Creative Commons license, and indicate if changes were made. 


\section{INTRODUCTION}

In the recent days, the awareness on the treasury that is the plant kingdom, which is flooded with such potential drugs has increased ${ }^{1}$. Bacteria have developed multiple defense mechanisms against antimicrobial drugs where a few are becoming multidrug resistant as well ${ }^{2}$. Hence novel methods must be simultaneously developed to eradicate such bacteria. Medicinal plants are known for their tremendous application in the medicinal world since long ago. These plants not only act as antimicrobial compounds but also suppress peroxidation by reacting with free radicals expressing anti-oxidant activity. The plants and their parts are known to contain certain bioactive compounds such as tannins, saponins, essential oils and more other metabolites ${ }^{3}$. These plants do also help in the production of nanoparticles ${ }^{4-6}$.

Nano biotechnology is the fast-rising sector in the present era. Metal nanoparticles are known for their structural flexibility and functionality?. Hence these nanoparticles find application in medicine, catalysts, contrasting agent etc ${ }^{8}$. Silver has been known for treating burns and wounds to prevent infections for centuries ${ }^{9}$. There are reports stating that silver nanoparticles are non-toxic to humankind but lethal to microorganisms ${ }^{10}$. There are a lot of methods exploited to synthesize silver nanoparticles viz., chemical, radiation, electrochemical and photochemical methods ${ }^{11}$. Although out of these methods, the chemical method produces a high yield for low cost, they have their own drawbacks such as contamination due to precursors, utilization of toxic solvents and generation of toxic byproducts. Hence biological approaches are adopted for the synthesis due to its abilities like cost effectiveness, non-toxic nature, ability to produce high yield, energy efficiency and environmental friendly ${ }^{12}$. The biological methods of nanoparticle production involve the action of plants, enzymes and fungi. But out of these the plant based nanoparticles are found to be efficient and safe for human therapeutic usage ${ }^{13}$. Plant metabolites are responsible for the formation of silver ions by reducing silver nitrate ${ }^{4}$. With these evidences, the present investigation focuses on the understanding of the bioactivity of selected four medicinal plants viz., Datura metel, Aegle marmelos, Annona reticulata and Saraca indica, the utilization of extracts of the same for silver nanoparticle production, the characterization of the nanoparticles produced and their antibacterial effect.

\section{MATERIALS AND METHODS Chemicals}

The following chemicals were bought from SRL, India and all the reagents were analytical grade: Acetone, Benzene, Chloroform, Methanol, Petroleum ether, DPPH, Ferric chloride, Conc. Sulphuric acid, Conc. Hydrochloric acid, Dragendorff's reagent, Benedict's reagent, Potassium ferricyanide, Trichloroacetic acid, Ethanol, Sodium chloride, Ethyl acetate, Ammonium molybdate, Nitric acid, Copper acetate solution, Conc. Ammonium hydroxide, Sodium hydroxide, EDTA and Ferric chloride.

\section{Sample collection}

Datura metel, Aegle marmelos, Annona reticulata and Saraca indica leaves were chosen and procured from different localities of Chennai, Tamil Nadu. The healthy leaves were rinsed in water, shade dried, powdered and then stored for extraction.

\section{Preparation of the extract}

Plant powder was extracted with three solvents, namely Water, Ethanol and Chloroform. $10 \mathrm{~g}$ plant powder was taken in $100 \mathrm{~mL}$ of respective solvent (water, ethanol and chloroform). Plants leaves were macerated, filtered and concentrated using oven at $50^{\circ} \mathrm{C}$.

\section{Phytochemical analysis}

Phytochemicals were screened for all the four plants ${ }^{14}$.

\section{Antibacterial activity}

Briefly, Pseudomonas aeruginosa was spread over nutrient agar under aseptic conditions and wells were filled with different concentrations $(2 \mu \mathrm{g}, 4 \mu \mathrm{g}, 8 \mu \mathrm{g}$ and $16 \mu \mathrm{g})$ of the crude extracts and incubated at $37^{\circ} \mathrm{C}$ for $24 \mathrm{~h}$. Inhibition zone was noted. Ciproflaxacin was exploited as positive control and their respective solvents as negative control ${ }^{15}$.

\section{TLC and bioautography analysis}

Each solvent extract was subjected to TLC bioautography (Merck, F245). The TLC plates were cut into required sizes and were solvent 
vapor-saturated in TLC glass chamber ${ }^{16}$. Sample was loaded onto TLC plate using capillary tube and run against the mobile phase i.e. Chloroform: Methanol (8:2). The Retention factor (Rf) was noted after exposing them to iodine. Antioxidant and antibacterial activity were detected on TLC plate as mentioned earlier ${ }^{17,18}$. The Rf values of the samples were calculated.

\section{Antioxidant assays}

Various antioxidant assays were performed for the metabolites namely FRAP assay $^{19}$, DPPH assay ${ }^{20}$.

\section{Synthesis of silver nanoparticles}

The four various plant leaf extracts were subjected for silver nanoparticles as described by earlier studies, ${ }^{21}$ except for chloroform extracts of the plants since they are immiscible in water.

\section{Characterization of silver nanoparticles}

Silver nanoparticles were characterized by UV-Vis analysis ${ }^{22,23}$, SEM (Scanning Electron Microscopy) ${ }^{24}$.

\section{Antibacterial activity}

The antibacterial activity of silver nanoparticles was evaluated against the gramnegative bacterial species Pseudomonas aeruginosa by following Saravanakumar et al. ${ }^{25}$.

\section{RESULT AND DISCUSSIONS \\ Phytochemical Analysis}

Aqueous, ethanol and chloroform extracts of Datura metel, Annona reticulata, Aegle marmelos, Saraca indica leaves were quantitatively analyzed (Table 1). Screening confirmed Alkaloids, Saponins and Tannins presence in all extracts. Carbohydrates were noticed to be present in all three solvents of Saraca indica and aqueous extract of Datura metel. Phytosterols were absent in almost all extracts except aqueous extract of Datura metel and Saraca indica whereas phenols were found in chloroform extracts of Aegle marmelos and Saraca indica. Datura metel was reported to possess saponins and other phytochemicals ${ }^{26}$. Biologically active compounds can play a vital role in the pharmaceutical industries possessing pharmacological activities. Each of the phytochemicals have different bioactivities like antibiotic, analgesic etc ${ }^{27}$.

\section{Antibacterial Activity}

Datura metel's ethanolic extract was having antibacterial activity (Table 2), which is on par with the earlier report of Akharaiyi ${ }^{26}$. Chloroform extract of Datura metel was found to be non-effective against P.aeruginosa used in this study, which is contradictory to the result of Vadlapudi and Kaladhar ${ }^{28}$, where they found chloroform extract of Datura metel to have antibacterial activity against Erwinia caratovara and Pseudomonas syringae. Aqueous extract of Annona reticulata shows maximum zone of inhibition followed by ethanol extract of Aegle marmelos against the bacteria Pseudomonas aeruginosa.

Table 1. Phytochemical analysis of medicinal plants chosen for this study

\begin{tabular}{|c|c|c|c|c|c|c|c|c|c|c|c|c|}
\hline \multirow[t]{2}{*}{ Phytochemical } & \multicolumn{3}{|c|}{ D. metel } & \multicolumn{3}{|c|}{ A. marmelos } & \multicolumn{3}{|c|}{ S. indica } & \multicolumn{3}{|c|}{ A. reticulata } \\
\hline & $\mathrm{H}$ & $E$ & $\mathrm{C}$ & $\mathrm{H}$ & $E$ & C & $\mathrm{H}$ & $E$ & $\mathrm{C}$ & $\mathrm{H}$ & $E$ & C \\
\hline Alkaloids & ++ & +++ & + & +++ & ++ & + & +++ & - & + & ++ & - & ++ \\
\hline Carbohydrates & ++ & - & - & + & - & - & ++ & +++ & ++ & + & + & - \\
\hline Glycosides & - & - & - & - & + & - & - & - & - & - & - & - \\
\hline Saponins & ++ & ++ & ++ & ++ & ++ & ++ & ++ & ++ & ++ & +++ & + & ++ \\
\hline Phytosterols & + & - & - & - & - & - & +++ & - & - & - & - & - \\
\hline Phenols & - & - & - & - & + & + & - & - & ++ & + & + & - \\
\hline Tannins & - & +++ & ++ & +++ & +++ & +++ & +++ & +++ & - & - & - & +++ \\
\hline Flavonoids & - & - & + & - & - & - & - & - & - & - & - & + \\
\hline $\begin{array}{l}\text { Protein and } \\
\text { aminoacids }\end{array}$ & - & - & - & - & - & - & ++ & - & - & - & - & - \\
\hline Diterpenes & - & - & - & - & - & - & - & - & - & - & - & - \\
\hline
\end{tabular}

+++ indicates immediate change, ++ indicates change which occurred within $5 \mathrm{~min},+$ indicates change that occurs after $5 \mathrm{~min}$; - indicates no such change 


\section{Thin Layer Chromatography}

Thin Layer Chromatography Exposed to lodine

Separation of compounds was done using thin layer chromatography and the TLC plates were exposed to iodine in iodine chamber ${ }^{18}$. Ethanol and chloroform extracts of Datura metel has shown the maximum of 3 bands (Fig. 1). The separated compounds were seen under ultra violet ray for the appearance of any extra bands, but no extra bands were found under ultra violet ray (Fig. 2), which is commonly used for observing other metabolites ${ }^{29}$.

Most of the extracts showed antioxidant activity, 3 bands of Chloroform extract of Datura metel has shown anti-oxidant activity, even chloroform extract of Aegle marmelos showed antioxidant activity (Fig. 3). TLC bioautography for antioxidant activity was identified in Aegle marmelos ${ }^{30}$.

TLC bioautography for antibacterial activity helps in identifying the compound which shows antibacterial activity in TLC plate itself. Antibacterial activity of Punica granatum, Acacia senegal and Mangifera indica ${ }^{18,31,32}$ has been reported by TLC bioautography. Ethanolic and chloroform extracts exhibited antibacterial activity in TLC plate itself (Fig. 4).

\section{Assay for Antioxidant activity}

All the plants showed antioxidant activity

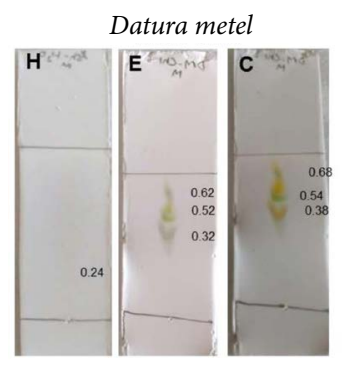

Saraca indica

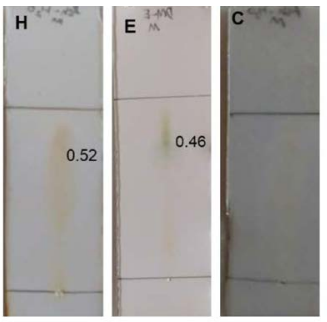

Fig. 1. lodine exposed Thin layer chromatography of medicinal plants chosen for this study. $\mathrm{H}$ - aqueous extract, $\mathrm{E}$ - ethanol extract, C- Chloroform extract
(Fig. 5 and 6). In a study, it is reported by FRAP assay that leaf of Datura metel has more antioxidant activity than bark ${ }^{26}$. Chloroform extract of Annona reticulata possessed more scavenging activity (Fig. 6). The antioxidant activity was even comparable with ascorbic acid ${ }^{33,34}$. Reducing powers and scavenging activity of various medicinal plants were reported earlier ${ }^{35,36}$.

\section{Characterization of silver nanoparticles UV-Visible Spectroscopy}

Phytochemical compounds do reduce the $\mathrm{Ag}^{+}$to $\mathrm{Ag}^{0}$, but it also imparts stability of nanoparticles ${ }^{37}$. Silver nanoparticles produced using ethanol extracts showed peaks near 420nm (Fig. 7) but water extract mediated silver nanoparticles were showing peak nearing 200$250 \mathrm{~nm}$. For the Ethanol extract of Saraca indica, Annona reticulata and Aegle marmelos, the peaks range at $600-630 \mathrm{~nm}$. Efforts were made to produce silver nanoparticles using Annona muricata and the particles were found to show absorbance at $420 \mathrm{~nm}^{38}$. In this study, silver nanoparticle produced using ethanol extract of Datura metel was found to show absorbance near $420 \mathrm{~nm}$ to $440 \mathrm{~nm}$, where it is on par with the absorbance of silver nanoparticles produced ${ }^{39,40}$.
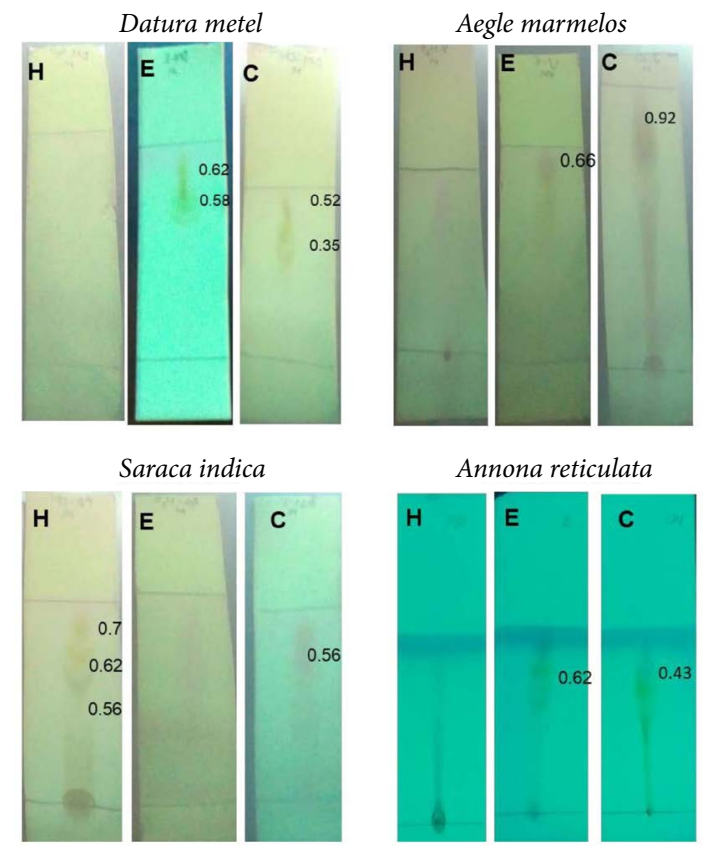

Fig. 2. UV light exposed Thin layer chromatography of medicinal plants chosen for this study. $\mathrm{H}$ - aqueous extract, E - ethanol extract, C- Chloroform extract 
Table 2. Antibacterial activity of various extracts

\begin{tabular}{|c|c|c|c|c|c|c|c|c|c|c|c|c|}
\hline \multirow[t]{2}{*}{ Components } & \multicolumn{4}{|c|}{$\begin{array}{l}\text { Water extract } \\
\text { Zone of inhibition } \\
\text { (diameter in } \mathrm{cm} \text { ) }\end{array}$} & \multicolumn{4}{|c|}{$\begin{array}{l}\text { Ethanol extract } \\
\text { Zone of inhibition } \\
\text { (diameter in } \mathrm{cm} \text { ) }\end{array}$} & \multicolumn{4}{|c|}{$\begin{array}{l}\text { Chloroform extract } \\
\text { Zone of inhibition } \\
\text { (diameter in } \mathrm{cm} \text { ) }\end{array}$} \\
\hline & $\mathrm{DM}$ & AM & SI & AR & DM & AM & SI & $A R$ & DM & AM & $\mathrm{SI}$ & AR \\
\hline $2 \mu \mathrm{g}$ & -ve & 0.1 & 0.1 & 0.1 & 0.2 & 0.1 & 0.1 & -ve & -ve & 0.2 & -ve & 0.2 \\
\hline $4 \mu \mathrm{g}$ & -ve & 0.1 & 0.2 & 0.3 & 0.3 & 0.1 & 0.1 & -ve & -ve & 0.3 & -ve & 0.2 \\
\hline $8 \mu \mathrm{g}$ & -ve & 0.3 & 0.2 & 0.4 & 0.4 & 0.3 & 0.2 & -ve & -ve & 0.3 & -ve & 0.4 \\
\hline $16 \mu \mathrm{g}$ & -ve & 0.5 & 0.3 & 0.5 & 0.8 & 0.4 & 0.3 & 0.2 & -ve & 0.4 & -ve & 0.4 \\
\hline $\begin{array}{l}\text { Positive } \\
\text { Control } \\
\text { (Ciprofloxacin) }\end{array}$ & 0.9 & 1.0 & 0.9 & 1.1 & 1.2 & 1.2 & 1.2 & 0.9 & 0.9 & 1.2 & 0.8 & 0.9 \\
\hline
\end{tabular}

Table 3. Antibacterial activity of green synthesized silver nanoparticles

\begin{tabular}{|c|c|c|c|c|c|c|c|c|}
\hline \multirow[t]{2}{*}{ Components } & \multicolumn{4}{|c|}{$\begin{array}{l}\text { Water extract } \\
\text { Zone of inhibition } \\
\text { (diameter in } \mathrm{cm} \text { ) }\end{array}$} & \multicolumn{4}{|c|}{$\begin{array}{l}\text { Ethanol extract } \\
\text { Zone of inhibition } \\
\text { (diameter in } \mathrm{cm} \text { ) }\end{array}$} \\
\hline & DM & AM & SI & $A R$ & DM & AM & SI & $A R$ \\
\hline $2 \mu g$ & -ve & -ve & -ve & -ve & -ve & -ve & -ve & -ve \\
\hline $4 \mu \mathrm{g}$ & -ve & -ve & -ve & -ve & -ve & -ve & -ve & -ve \\
\hline $8 \mu \mathrm{g}$ & -ve & -ve & -ve & -ve & -ve & -ve & -ve & -ve \\
\hline $16 \mu \mathrm{g}$ & -ve & -ve & -ve & -ve & -ve & -ve & -ve & -ve \\
\hline
\end{tabular}

DM - Datura metel, AM - Aegle marmelos, SI - Saraca indica, AR - Annona reticulata, -ve - negative

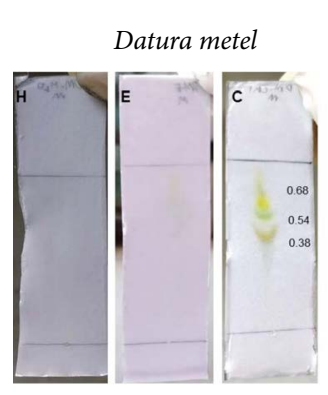

Aegle marmelos
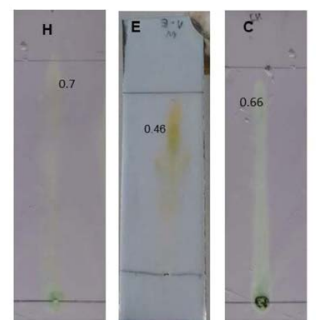

Fig. 3. TLC bioautography for antioxidant activity of medicinal plants chosen for this study. $\mathrm{H}$ - aqueous extract, E - ethanol extract, C- Chloroform extract
Datura metel

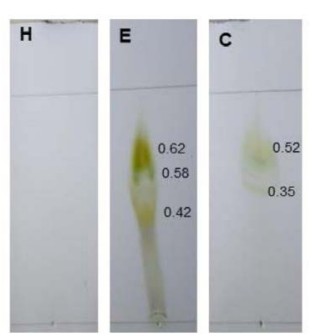

Aegle marmelos

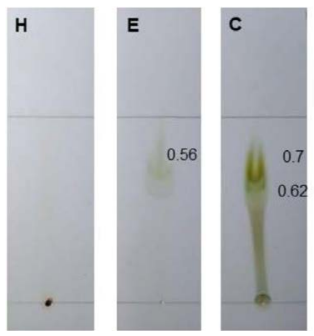

Fig. 4. TLC bioautography for Antibacterial activity of medicinal plants chosen for this study.

$\mathrm{H}$ - aqueous extract, $\mathrm{E}$ - ethanol extract, C-Chloroform extract 


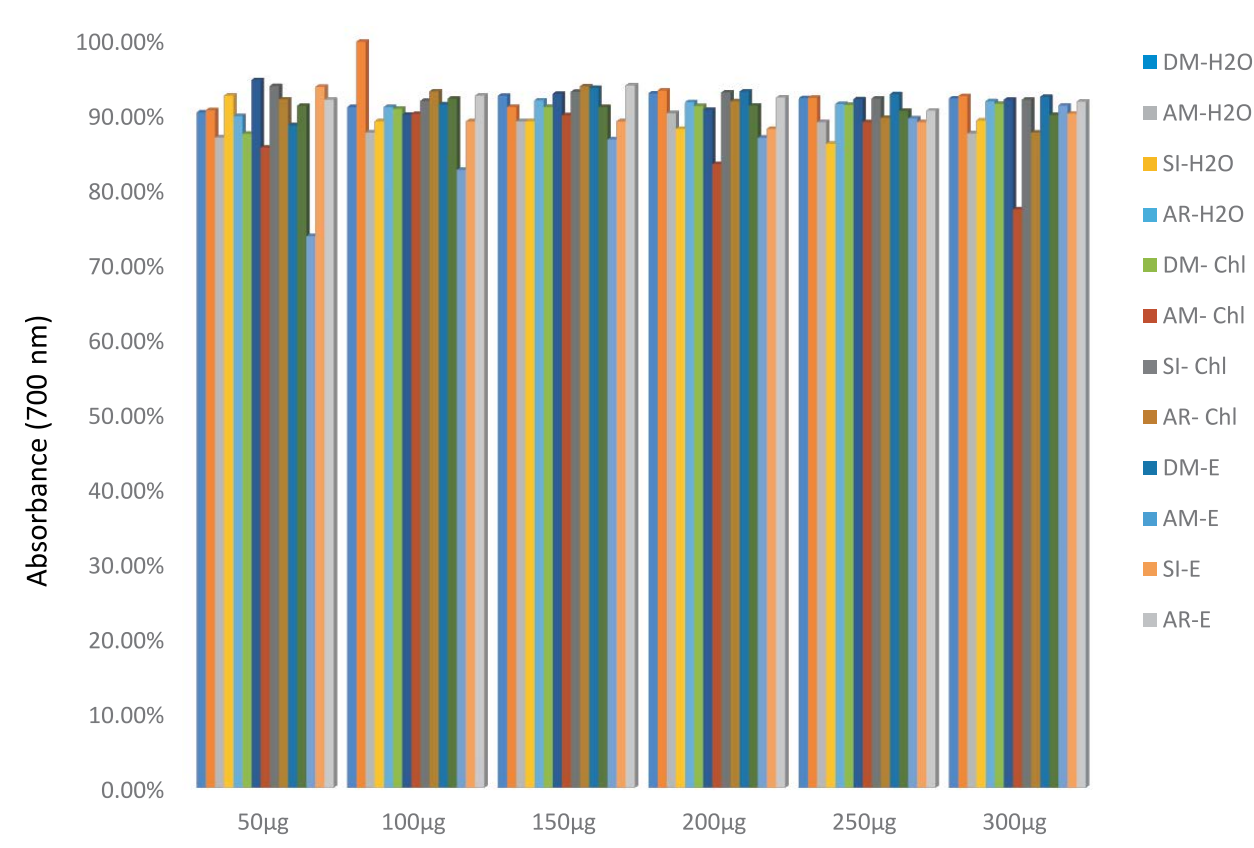

Fig. 5. Iron reducing activity of medicinal plants chosen for this study by FRAP assay.

DM- $\mathrm{H}_{2} \mathrm{O}$ - aqueous extract of Datura metel, AM- $\mathrm{H}_{2} \mathrm{O}$ - aqueous extract of Aegle marmelos, $\mathrm{SI}-\mathrm{H}_{2} \mathrm{O}$ - aqueous extract of Saraca indica, AR-H2O - aqueous extract of Annona reticulata, DM-chl-chloroform extract of Datura metel, AM-chl-chloroform extract of Aegle marmelos, SI-chl - chloroform extract of Saraca indica, AR-chl - chloroform extract of Annona reticulata, DM-E- ethanol extract of Datura metel, AM-E- ethanol extract of Aegle marmelos, SI-E- ethanol extract of Saraca indica, AR- -E- ethanol extract of Annona reticulata

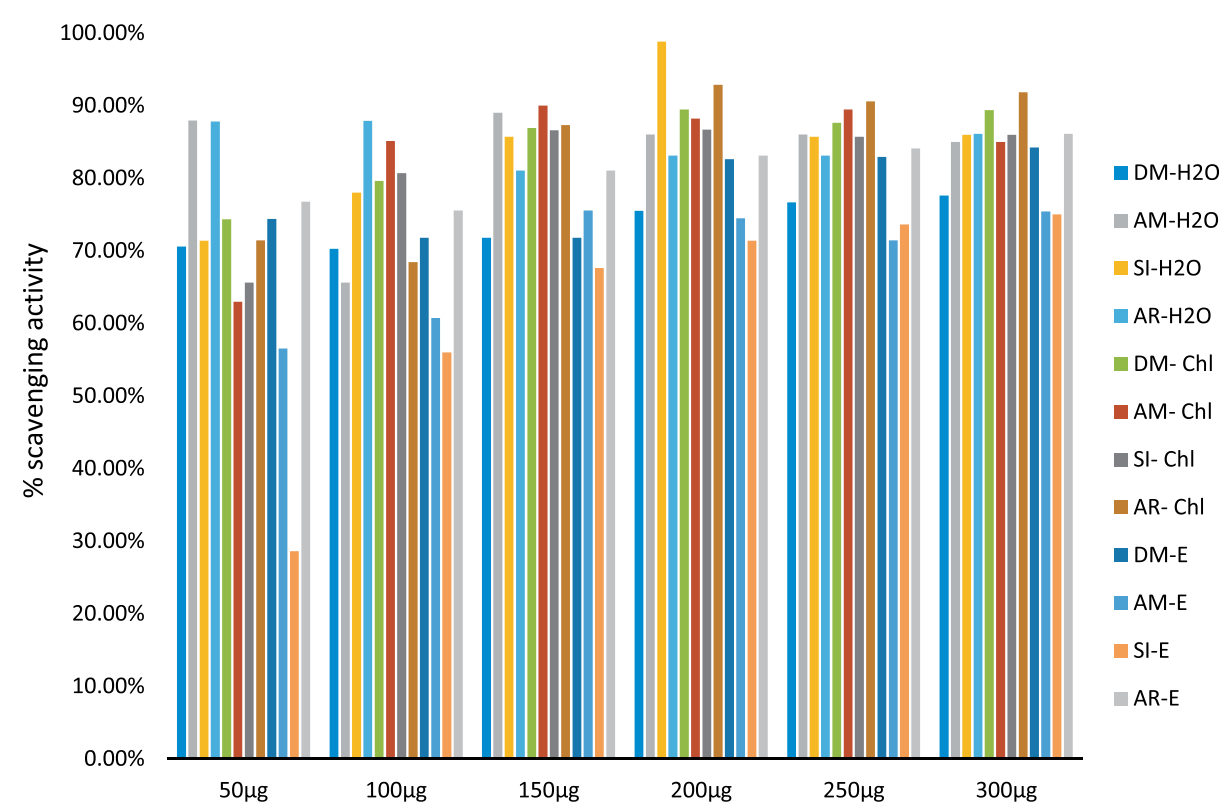

Fig. 6. Free radical scavenging activity of medicinal plants chosen for this study by DPPH assay.

DM- $\mathrm{H}_{2} \mathrm{O}$ - aqueous extract of Datura metel, AM- $\mathrm{H}_{2} \mathrm{O}$ - aqueous extract of Aegle marmelos, $\mathrm{SI}-\mathrm{H}_{2} \mathrm{O}-$ aqueous extract of Saraca indica, AR- $\mathrm{H}_{2} \mathrm{O}$ - aqueous extract of Annona reticulata, DM-chl - chloroform extract of Datura metel, AM-chl - chloroform extract of Aegle marmelos, Sl-chl - chloroform extract of Saraca indica, AR-chl - chloroform extract of Annona reticulata, DM-E- ethanol extract of Datura metel, AM-E- ethanol extract of Aegle marmelos, SI-E- ethanol extract of Saraca indica, AR- -E- ethanol extract of Annona reticulata 

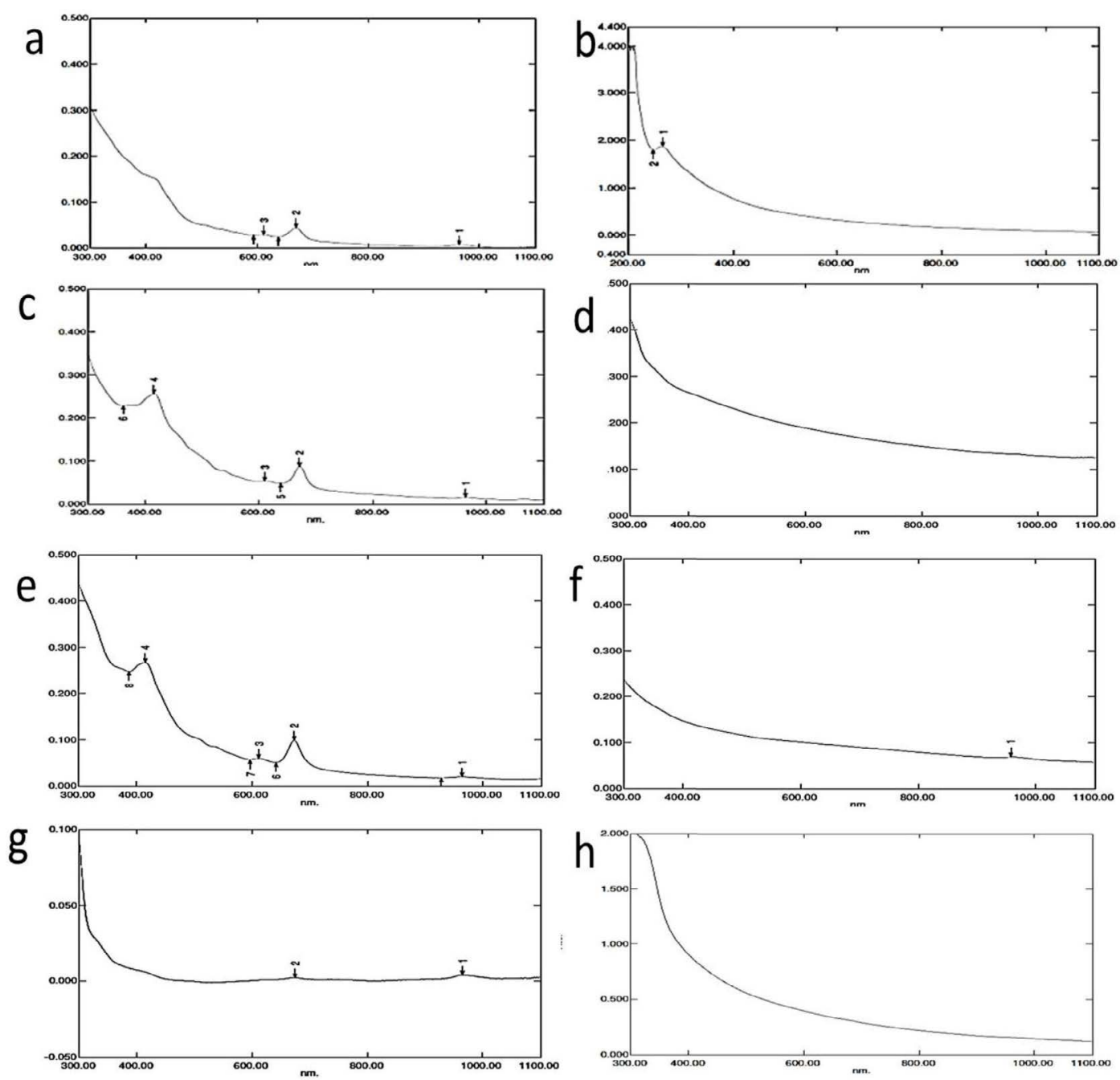

Fig. 7. UV-visible spectroscopy analysis of silver nanoparticles

a) Saraca indica (ethanol) b) Saraca indica (water) c) Annona recticulata (ethanol) d) Annona recticulata (water) e) Datura metel (ethanol) f) Datura metel (water) g) Aegle marmelos (ethanol) h) Aegle marmelos (water)

\section{Scanning Electron Microscopy}

Size ranging from 45 to $120 \mathrm{~nm}$ was found for silver nanoparticles produced. Nanoparticles produced using Aegle marmelos ranged from 47 to $52 \mathrm{~nm}$ (Fig. $8 \mathrm{~h}$ ) and was recorded to be the smallest in the group where Saraca indica induced nanoparticles were ranging from 90 to $110 \mathrm{~nm}$ recorded to be the largest nanoparticle in the group. (Fig. 8a). 35nm - 60nm sized particles were produced using Aegle marmelos s $^{41,39}$. Using methanolic extract of Annona muricata, $22 \mathrm{~nm}$ sized nanoparticles were made ${ }^{38}$.

\section{Antibacterial activity}

There was no activity against the bacteria used (Table 3 ), which is contradictory to earlier reports ${ }^{42}$, where it was found that nanoparticles produced using Aegle marmelos to have antibiofilm activity. There are more evidences that silver nanoparticles synthesized using plant extracts have antibacterial activity ${ }^{43}$. Extract of Annona squamosa has been reported to produce silver nanoparticles with anti-microbial activity ${ }^{44}$. 

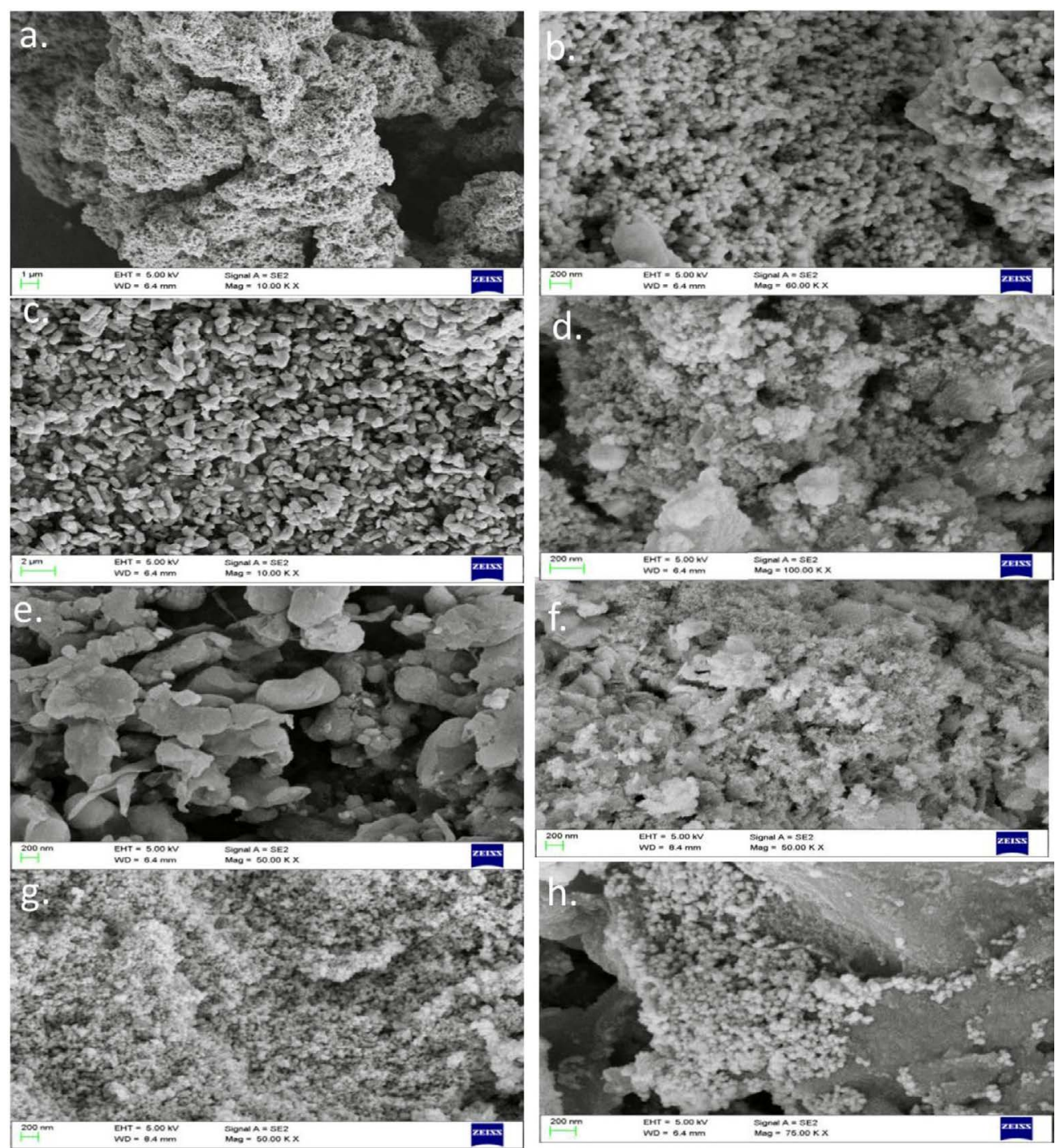

Fig. 8. SEM analysis of silver nanoparticle produced using different extracts

a) Saraca indica(ethanol),b) Saraca indica(water), c) Annona recticulata (ethanol), d) Annona recticulata (water), e) Datura metel(ethanol), f) Datura metel (water), g) Aegle marmelos (ethanol), h) Aegle marmelos (water)

\section{CONCLUSION}

Datura metel, Aegle marmelos, Annona reticulata and Saraca indica leaves were collected and subjected to solvent extraction. Extracts were analysed for its phytoconstituent and bioactivity study. All plants were found to possess antibacterial as well as antioxidant activity Plant mediated silver nanoparticles did not show any antibacterial activity against Pseudomonas aeruginosa.

\section{ACKNOWLEDGMENT}

None

\section{CONFLICT OF INTERESTS}

The author declares that there are no conflict of interest.

\section{REFERENCES}

1. Yadav, R.N.S., Agarwala M. Phytochemical analysis of some medicinal plants. Journal of phytology, 2011; 3(12). 
2. Ahmad, I. and Aqil, F. In vitro efficacy of bioactive extracts of 15 medicinal plants against ESגL-producing multidrug-resistant enteric bacteria. Microbiological Research, 2007; 162(3): 264-275.

3. Samrot, A. V., Shobana, N., Jenna, R. Antibacterial and antioxidant activity of different staged ripened fruit of Capsicum annuum and its green synthesized silver nanoparticles. BioNanoSci, 2018; 8: 632-646. https:// doi.org/10.1007/s12668-018-0521-8

4. Samrot, A.V., Raji, P., Selvarani, A.J., Nishanthini, P. Antibacterial activity of some edible fruits and its green synthesized silver nanoparticles against uropathogen - Pseudomonas aeruginosa SU 18. Biocatalysis and Agricultural Biotechnology, 2018, 16: 253-270.

5. Krishnaraj, C., Jagan, E. G., Rajasekar, S., Selvakumar, P., Kalaichelvan, P. T., Mohan, N. Synthesis of silver nanoparticles using Acaly-phaindica leaf extracts and its antibacterial activity against water borne pathogens. Colloids and Surfaces B: Biointerfaces, 2010; 76(1): 50-56.

6. Iravani, S. Green synthesis of metal nanoparticles using plants. Green Chemistry, 2011; 13(10): 2638-2650.

7. Maruthai, K., Vallayyachari, K., Ravibalan, T., Philip, S. A., Samrot, A. V., Muthuraj, M. Antibacterial Activity of the Silver Nanoparticles against Escherichia coli and Enterobacter sp. Progress in Bioscience and Bioengineering, 2017; 1(1).

8. Vidhu, V. K., Philip, D. Spectroscopic, microscopic and catalytic properties of silver nanoparticles synthesized using Saraca indica flower. Spectrochimica Acta Part A: Molecular and Biomolecular Spectroscopy, 2014; 117 102-108.

9. Blecher, K., Nasir, A., Friedman, A. The growing role of nanotechnology in combating infectious disease. Virulence, 2011; 2(5):395-401.

10. Savithramma, N., Rao, M. L., Rukmini, K., Devi, P. S. Antimicrobial activity of silver nanoparticles synthesized by using medicinal plants. International Journal of ChemTech Research, 2011; 3(3): 1394-1402.

11. Vivek, R., Thangam, R., Muthuchelian, K., Gunasekaran, P., Kaveri, K., Kannan, S. Green biosynthesis of silver nanoparticles from Annona squamosa leaf extract and its in vitro cytotoxic effect on MCF-7 cells. Process Biochemistry, 2012; 47(12): 2405-2410.

12. Thakkar, K. N., Mhatre, S. S., Parikh, R. Y. Biological synthesis of metallic nanoparticles. Nano-medicine: Nanotechnology, Biology and Medicine, 2010; 6(2):257-262.

13. Ponarulselvam, S., Panneerselvam, C., Murugan, K., Aarthi, N., Kalimuthu, K., Thangamani, K. S. Synthesis of silver nanoparticles using leaves of Catharanthus roseus Linn. G. Don and their antiplasmodial activities. Asian Pacific journal of tropical biomedicine, 2012; 2(7): 574-580.

14. Harbone, J. B. Methods of extraction and isolation. Phy-tochemical Methods, 1998, pp. 60- 63, 90-93, 129-132, 203-207 and 214-216. Chapman and Hall, London.

15. Jahangirian, H., Ismail, M. H. S., Haron, M. J., Rafiee-Moghaddam, R., Shameli, K., Hosseini, S., et al. Synthesis and characterization of zeolite/ Fe304 nanocomposite by green quick preci-pitation method. Dig. J. Nanomaterials Bios, 2013; 4(8): 4.

16. Sherma, J. Thin-layer chromatography in food and agricultural analysis. Journal of Chromatography $A$, 2000; 880: 129-147.

17. Mensor, L. L., Menezes, F. S., Leitao, G. G., Reis, A. S., Santos, T. C. D., Coube, C. S., Leitao, S. G. Screening of Brazilian plant extracts for antioxidant activity by the use of DPPH free radical method. Phytotherapy Research, 2001; 15: 127-30.

18. Samrot, A. V., Rohan, B. D., Sahiti, K., Raji, P., Kumar, D. M., Geethika, R. G. TLC bioautography guided identification of antioxidant and antibacterial activity of various extracts of Punica granatum. Journal of Chemical and Pharma-ceutical Research, 2016; 8(5): 815-820.

19. Benzie, F. F., Strain, J. J. Ferric reducing/antioxidant power assay: direct measure of total antioxidant activity of biological fluids and modified version for simultaneous measurement of total antioxidant power and ascorbic acid concentration. Methods in enzymology, 1999; 299: 15-27.

20. Maizura, M., Aminah, A., Wan Aida, W. N. Total phenolic content and antioxidant activity of kesum (Polygonum minus), ginger (Zingiber officinale) and turmeric (Curcuma longa) extract. International Food Research Journal, 2001; 18: 529-534.

21. Kharat, N. S., Mendhulkar, V. D. Synthesis, characterization and studies on antioxidant activity of silver nanoparticles using Elephanto pusscaber leaf extract. Materials Science and Engineering C, 2016; 62: 719-724.

22. Banala, R. R., Nagati, V. B., Karnati, P. R. Green synthesis and characterization of Carica papaya leaf extract coated silver nanoparticles through $\mathrm{X}$-ray diffraction, electron microscopy and evaluation of bactericidal properties. Saudi Journal of Biological Sciences, 2015; 22: 637-644.

23. Rajathi, K., Sridhar, S. Green synthesized silver nanoparticles from the medicinal plant Wrightia tinctoria and its antimicrobial potential. Int I Chem Tech Res, 2013; 5(4): 1707-1713.

24. Sriranjani, R., Srinithya, B., Vellingiri, V., Brindha, P., Anthony, S. P., Sivasubramanian, A., Muthuraman, M. S. Silver nanoparticle synthesis using Clerodendrum phlomidis leaf extract and preliminary investigation of its antioxidant and anticancer activities. Journal of Molecular Liquids, 2016; 220: 926-930.

25. Saravanakumar, A., Peng, M. M., Ganesh, M., Jayaprakash, J., Mohankumar, M., Jang, H. T. Low-cost and eco-friendly green synthesis of silver nanoparticles using Prunus japonica (Rosaceae) leaf extract and their antibacterial, antioxidant properties. Artificial Cells, Nanomedicine, and Biotechnology, 2017; 45(6): 1165:1171.

26. Akharaiyi, F. C. Antibacterial, Phytochemical and Antioxidant activities of Datura metel. International Journal of PharmTech Research, 2011; 3: 478-483.

27. Amin, M. M., Sawhney, S. S., Jassal, M. M. S. Wudpecker. Qualitative and quantitative analysis of phytochemicals of Taraxacum offi-cinale. Journal of Pharmacy and Pharmocology, 2013; 2(1): 001 -005.

28. Vadlapudi, V., Kaladhar, D. S. V. G. K. Antimicrobial 
study of plant extracts of Datura metel L. against some important disease causing pathogens. Asian Pacific Journal of Tropical Disease, 2012; 2: 94-S97.

29. Kalaivani, T., Mathew, L. Free radical scavenging activity from leaves of Acacia nilotica (L.) Wild. ex Delile, an Indian medicinal tree. Food and Chemical Toxicology, 2010; 48(1): 298-305.

30. Victoria, D. T., Samrot, A. V. Identification of antioxidant activity of bark of Aegle marmelos. Der Pharma Chemica, 2016; 8(18): 359-363

31. Samrot, A. V., Rohan, B. D., Kumar, D., Sahiti, K., Raji, P., Samanvitha, S. K. Detection of antioxidant and antibacterial activity of Mangifera indica using tlc bioautography. International Journal of Pharmaceutical Sciences and Research, 2016; 7(11): 4467-4472.

32. Samrot, A. V., Sahiti, K., Raji, P., Rohan, B. D., Kumar, D., Sharma, K. TLC bio-autography guided identification of antioxidant and antibacterial activity of Acacia senegal. Der Pharmacia Lettre, 2016; 8(9): 41-47.

33. Jamkhande, P. G., Pathan, S. K., Wadher, S. J. In silico PASS analysis and determination of antimycobacterial, antifungal, and antioxidant efficacies of maslinic acid in an extract rich in pentacyclic triterpenoids. International Journal of Mycobacteriology, 2016; 5(4): 417-425.

34. Jamkhande, P. G., Suryawanshi, V. A., Kaylankar, T. M., Patwekar, S. L. Biological activities of leaves of ethnomedicinal plant, Borassus flabellifer Linn. (Palmyra palm): An antibacterial, antifungal and antioxidant evaluation. Bulletin of Faculty of Pharmacy, Cairo University, 2016; 54(1): 59-66.

35. Chyau, C. C., Tsai, S. Y., Ko, P. T., Mau, J. L. Antioxidant properties of sol- vent extracts from Terminalia catappa leaves. Food Chemistry, 78(4): 483-488.

36. Abdulkadir, A. R. In Vitro Antioxidant Activity of Ethanolic Extract from Terminalia catappa (L.) Leaves and Fruits: Effect of Fruit Ripening. International Journal of Science and Research, 2015; 4(8): 1244 $-1249$.
37. Vidhu, V. K., Aromal, A., Philip, D. Green synthesis of silver nanoparticles using Macrotyloma uniflorum. Acta Part A Mol Biomol Spectrosc, 2011; 83(9): 392-397.

38. Ezealisiji, K. M., Noundou, X. S., Ukwueze, S. E. Green synthesis and characterization of monodispersed silver nanoparticles using root bark aqueous extract of Annona muricata Linn and their antimicrobial activity. Applied Nanoscience, 2017; 7(8): 905-911.

39. Gomathi, M., Rajkumar, P. V., Prakasam, A., Ravichandran, K. Green synthesis of silver nanoparticles using Datura stramonium leaf extract and assessment of their antibacterial activity. Resource-Efficient Technologies, 2017; 3(3): 280-284.

40. Singh, M., Mallick, A. K., Banerjee, M., Kuma, R. Loss of outer membrane integrity in Gram-negative bacteria by silver nanoparticles loaded with Camellia sinensis leaf phytochemicals: plausible mechanism of bacterial cell dis-integration. Bull. Mater. Sci, 2016; 39(37): 1871-1878.

41. Rao, K. J. and Paria, S. Green synthesis of silver nanoparticles from aqueous Aegle marmelos leaf extract. Materials Research Bulletin, 2013; 48(2): 628634.

42. Krupa, N. D. A. and Raghavan, V. Biosynthesis of silver nanoparticles using Aegle marmelos (Bael) fruit extract and its application to prevent adhesion of bacteria: a strategy to control microfouling. Bioinorganic chemistry and applications, 2014.

43. Singh, K., Panghal, M., Kadyan, S., Yadav, J. P. Evaluation of Antimicrobial Activity of Synthesized Silver Nanoparticles using Phyllanthus amarus and Tinospora cordifolia Medicinal Plants. J Nanomed Nanotechnol, 2014; 5(250).

44. Jagtap, U. B., Bapat, V. A. Biosynthesis, characterization and antibacterial activity of silver nanoparticles by aqueous Annona squamosa L. leaf extract at room temperature. Journal of Plant Biochemistry and Biotechnology, 2013; 22(4): 434-440. 